\title{
Effects of Dietary Supplementation of Humic Substances on Production Parameters, Immune Status and Gut Microbiota of Laying Hens
}

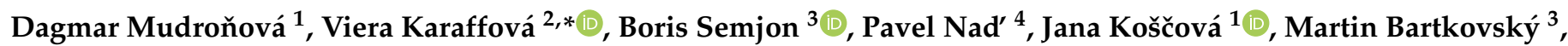 \\ Andrej Makiš ${ }^{3}$, Lukáš Bujňák ${ }^{4}$, Jozef Nagy $^{3}$, Jana Mojžišová ${ }^{5}$ and Slavomír Marcinčák ${ }^{3, *}$
}

1 Department of Microbiology and Immunology, University of Veterinary Medicine and Pharmacy in Košice, Komenského 73, 04181 Košice, Slovakia; dagmar.mudronova@uvlf.sk (D.M.); jana.koscova@uvlf.sk (J.K.)

2 Department of Morphological Disciplines, University of Veterinary Medicine and Pharmacy in Košice, Komenského 73, 04181 Košice, Slovakia

3 Department of Food Hygiene, Technology and Safety, University of Veterinary Medicine and Pharmacy in Košice, Komenského 73, 04181 Košice, Slovakia; boris.semjon@uvlf.sk (B.S.); martin.bartkovsky@uvlf.sk (M.B.); andrej.makis@student.uvlf.sk (A.M.); jozef.nagy@uvlf.sk (J.N.)

4 Department of Nutrition, Dietetics and Animal Breeding, University of Veterinary Medicine and Pharmacy in Košice, Komenského 73, 04181 Košice, Slovakia; pavel.nad@uvlf.sk (P.N.); lukas.bujnak@uvlf.sk (L.B.)

5 Department of Epizootology, Parasitology and Protection of One Health, University of Veterinary Medicine and Pharmacy in Košice, 04181 Košice, Slovakia; jana.mojzisova@uvlf.sk

check for updates

Citation: Mudroňová, D.;

Karaffová, V.; Semjon, B.; Nad', P.; Koščová, J.; Bartkovský, M.; Makiš, A.; Bujňák, L.; Nagy, J.; Mojžišová, J.; et al. Effects of Dietary Supplementation of Humic

Substances on Production Parameters, Immune Status and Gut Microbiota of Laying Hens. Agriculture 2021, 11, 744. https://doi.org/10.3390/ agriculture11080744

Academic Editor: Maria Grazia Cappai

Received: 12 July 2021

Accepted: 4 August 2021

Published: 6 August 2021

Publisher's Note: MDPI stays neutral with regard to jurisdictional claims in published maps and institutional affiliations.

Copyright: (c) 2021 by the authors. Licensee MDPI, Basel, Switzerland. This article is an open access article distributed under the terms and conditions of the Creative Commons Attribution (CC BY) license (https:/ / creativecommons.org/licenses/by/ $4.0 /)$.
* Correspondence: viera.karaffova@uvlf.sk (V.K.); slavomir.marcincak@uvlf.sk (S.M.); Tel.: +421-915-984-756 (S.M.)

\begin{abstract}
Despite the fact that humic substances (HS) have been frequently studied in relation to their effects on livestock health, studies on their influence on egg production and quality, immunity, and intestinal microbiota of laying hens are limited. In this study, the influence of $0.5 \%$ HS supplementation on the specific production parameters of eggshell mineral quality, immune parameters (relative expression of IgA, IGF-2, MUC-2 gene in cecum; activity of phagocytes, percentage of selected lymphocyte subpopulations in the peripheral blood), and number of lactic acid bacteria and enterobacteria in the intestinal contents in laying hens was tested. The addition of $0.5 \% \mathrm{HS}$ to the laying hen feed had a positive effect on egg laying rate, daily egg mass, egg weight, feed conversion and eggshell quality and also had an immunostimulatory effect manifested by increased phagocyte activity and B cell response. Concurrently, an increase in the number of enterobacteria in the intestinal contents and a decrease in the proportion of T lymphocytes $(p<0.05)$ was observed, which can be considered as a negative effect of HS. The results confirmed that HS can be used for the improvement of egg production and targeted immunostimulation, but their effect on the intestinal microbiota and $\mathrm{T}$ lymphocytes should be studied in more detail.
\end{abstract}

Keywords: humic substance; egg; immune answer; lymphocyte; intestinal microbiota

\section{Introduction}

Humic substances (HS) have a complex organic matter structure, which, among other things, reduces the toxic effect of herbicides, heavy metals, and soil-polluting radionuclides [1-4]. Moreover, it has been shown that HS transfer micronutrients, especially iron from soil to plants, and improve microbial populations in soils [5]. Active components of HS consist of humic acid, humus, ulmic acid, fulvic acid, humin, and certain microelements [6,7]. HS have primarily been used to stimulate plant growth [8], but they were also successfully applied in poultry nutrition, e.g., in various forms (natural and acidified HS) and concentrations $(0.25 \%$ of HS extract, $0.6 \%, 0.8 \%$, and $1.0 \%$ HS) [9-12].

Recently, trends in agriculture and animal feed applications are aimed at studying the impacts of various feed supplements targeting the enhanced health and productivity of the 
animals to produce healthy and safe food [13]. Egg quality and production are the most important economic factors in layer hen industry because worldwide egg consumption has been increasing in last decade [14]. Laying hen nutrition could be considered as one of the critical factors for optimizing egg quality in terms of nutritional composition or the economic aspects of whole egg production [15]. Novel nutritional approaches in poultry nutrition represent appropriate strategies for the improvement of animal feed conversion, mainly via feed ingredients or additives. Natural nutritional substances, such as antioxidants, vitamins, trace elements, etc., are well known for their positive impact on health and disease prevention in laying hens [16], while the use of HS in the diets of laying hens as feed additive is substantially new issue [17]. The productive performance and egg quality in layers could be affected by hen nutrition [18], and because of that, we assumed the improvement of the observed variables with HS supplementation in the diets of laying hens.

Nagaraju et al. [19] presented that the addition of humic acids to antibiotic-free feed improved the performance and immune status of broilers. Specifically, modulation of immune functions by means of HS also enables the support of health and production parameters. The effect of HS on the body's immune system is related to the ability of these substances to form relatively strong complexes with carbohydrates [20]. Consequently, these complexes make it possible to produce glycoproteins in the body, which are defined by the ability to bind to NK cells and T lymphocytes in order to act as modulators and to ensure subsequent communication between these cells. Thus, the ability of HS to affect the immune system lies in the regulation of immune activity and the prevention of excessive activity [21].

In addition, HS are also able to support the formation of a protective mucous film on the intestine epithelium, which has an impact on gut health [22]. Similarly, Islam et al. [23] reported positive effect of HS on farm animal health through the modification of the ecosystem in the intestine. HS allows for the better utilization of nutrients and improves not only gut health but also the quality of laid eggs [24]. Arpášová et al. [24] observed that the addition of humic acid in $0.5 \%$ concentration led to significantly higher egg production with an increased egg albumen index. Moreover, HS with supplementation with probiotic products based on lactobacilli significantly increased the egg albumen index and Haugh units. Sopoliga et al. [25] reported increased hatchability in pheasant laying hens after the intake of humic substances in comparison to hens fed with the conventional feed mixture.

However, scientific studies on the effect of HS supplementation in the diets laying hens on egg production and quality that are also supported by the immune parameters are limited. For this reason, our study was focused on the influence of $0.5 \%$ HS supplementation on the production parameters of eggshell mineral quality, immune parameters (relative expression of IgA, IGF-2, MUC-2 gene in cecum; activity of phagocytes, percentage of selected lymphocyte subpopulations (IgM+, CD3+, CD4+, CD8a+) in the peripheral blood), and the number of lactic acid bacteria and enterobacteria in the intestinal contents in laying hens.

\section{Materials and Methods}

\subsection{Experimental Design}

The animal protocol for this research was approved by the Ethical Committee for Animal Care and Use of University of Veterinary Medicine and Pharmacy in Košice (the Slovak Republic) and the Food Administration of the Slovak Republic (approved the experimental protocol number 3040/14-221). All procedures in this study were performed in accordance with the principles of the European Directive on the Protection of Vertebrate Animals Used for Experimental and Other Scientific Purposes (European Parliament and Council, 2010). The experimental diets were composed of commercial basal feed mixture with naturally occurring biogenic and heterogeneous organic substances as a HS supplement in accordance with regulation 68/2013 from 16 January 2013 of the European Union Commission, 
which states that the use of Leonardite is allowed as a source of HS as a feed component in animal diets.

A total of sixty laying hens of the Lohman Brown classic hybrid (Eggro-farm Ltd., Košická Polianka, Slovakia) in the 17th week of life were divided into two groups: the control $(\mathrm{C})$ group and experimental humic $(\mathrm{H})$ group. Each treatment group consisted of 30 birds (average weight $1.36 \pm 0.15 \mathrm{~kg}$ ). The control group (C) was fed with a basal feed mixture (De Heus, Bučovice, Czech Republic) without HS supplementation during the trial. The experimental group $(\mathrm{H})$ was fed with basic feed mixture supplemented with $0.5 \%$ dietary natural HS (Humac Ltd. Košice, Slovakia). The diet of the experimental group $(\mathrm{H})$ was prepared daily and was enriched with $\mathrm{HS}$ at a concentration of $0.5 \%$. The supplement was applied to the surface of the basal diet. The nutritional composition of the basal feed mixtures is presented in Table 1. The dietary natural HS supplement used in the experiment was ground and physically purified Leonardite without chemical treatment. It contained natural HS with more than $65 \%$ of humic acid without acid salts [12]. Laying hens were housed in floor pens with deep wood untreated litter in the form of being free range in secure and controlled microclimate conditions according to the Lohmann Brown Classic Management Guide [26]. The diet of the laying hens was formulated according to the recommended nutrient content for Lohmann Brown Classic hens [26]. The chemical compositions of the fermented feed and diets were determined for dry matter, crude protein, crude fat, crude fibre, starch, and total phosphorus according to the EC Commission Regulation 152/2009 [27] and Semjon et al. [28].

Table 1. Components and nutritional composition of laying hen diet.

\begin{tabular}{|c|c|c|}
\hline Component & \multicolumn{2}{|c|}{ Diet } \\
\hline Corn grain, $\%$ & \multicolumn{2}{|c|}{27.50} \\
\hline Wheat grain, $\%$ & \multicolumn{2}{|c|}{31.00} \\
\hline Barley grain, $\%$ & \multicolumn{2}{|c|}{7.50} \\
\hline Soybean meal, \% & \multicolumn{2}{|c|}{11.00} \\
\hline Corn gluten meal, $\%$ & \multicolumn{2}{|c|}{1.65} \\
\hline Rapeseed meal, \% & \multicolumn{2}{|c|}{1.70} \\
\hline Sunflower cake, $\%$ & \multicolumn{2}{|c|}{3.20} \\
\hline Sunflower oil, \% & \multicolumn{2}{|c|}{3.00} \\
\hline Wheat bran, \% & \multicolumn{2}{|c|}{5.00} \\
\hline Limestone, \% & \multicolumn{2}{|c|}{6.00} \\
\hline Monocalcium Phosphate, $\%$ & \multicolumn{2}{|c|}{1.25} \\
\hline Salt, \% & \multicolumn{2}{|c|}{0.20} \\
\hline Premix of amino acids, vitamins, and minerals $*, \%$ & \multicolumn{2}{|c|}{1.00} \\
\hline Ingredients & As Fed & Dry matter \\
\hline Dry matter, $\mathrm{g} \cdot \mathrm{kg}^{-1}$ & 899.00 & 1000.00 \\
\hline Crude protein, $\mathrm{g} \cdot \mathrm{kg}^{-1}$ & 157.50 & 175.19 \\
\hline Crude fat, $\mathrm{g} \cdot \mathrm{kg}^{-1}$ & 44.23 & 49.20 \\
\hline Crude fiber, $\mathrm{g} \cdot \mathrm{kg}^{-1}$ & 48.48 & 53.93 \\
\hline Ash, $\mathrm{g} \cdot \mathrm{kg}^{-1}$ & 128.60 & 143.05 \\
\hline Starch, $\mathrm{g} \cdot \mathrm{kg}^{-1}$ & 414.80 & 461.40 \\
\hline Calcium, $\mathrm{g} \cdot \mathrm{kg}^{-1}$ & 38.00 & 42.27 \\
\hline Phosphorus, $\mathrm{g} \cdot \mathrm{kg}^{-1}$ & 4.80 & 5.34 \\
\hline Sodium, $\mathrm{g} \cdot \mathrm{kg}^{-1}$ & 1.50 & 1.67 \\
\hline Copper, $\mathrm{mg} \cdot \mathrm{kg}^{-1}$ & 18.08 & 20.11 \\
\hline Zinc, $\mathrm{mg} \cdot \mathrm{kg}^{-1}$ & 65.90 & 73.30 \\
\hline Manganese, $\mathrm{mg} \cdot \mathrm{kg}^{-1}$ & 87.55 & 97.39 \\
\hline
\end{tabular}

* Premix of amino acids, vitamins, trace elements (per kg): lysine 140155 g; DL-methionine 180 g; vit. A 1,200,000 IU; D3 500,000 IU; E $2000 \mathrm{mg}$; pantothenic acid $1800 \mathrm{mg}$; niacin $6000156 \mathrm{mg}$; choline $60 \mathrm{mg}$; B6 500 mg; B12 1.8 mg; folic acid 200 mg; copper 1100 mg; iron 8400 mg; zinc 8000 mg; 157 manganese 12,000 mg; iodine $110 \mathrm{mg}$; selenium $40 \mathrm{mg}$. 
Laying hens were fed once a day with daily prepared diets. During weeks 17 and 18, they were fed $75 \mathrm{~g}$; in week 19, they were fed $81 \mathrm{~g}$; from week 20 to the laying phase, they were fed $93 \mathrm{~g}$; and during the laying phase, they were fed $100 \mathrm{~g}$ of diet/layer/day. Access of the layers to water was ad libitum. The lightening program from the 17th week of age was set to a lighting period of at least $10 \mathrm{~h}$, taking the natural day length into account, and it was increased by one hour every week up to $14 \mathrm{~h}$ until 21 weeks of age and remained stable from that point on [26]. Sufficient ventilation to ensure good litter condition was set. Their health and weight were monitored continuously. The experiment was finished when the laying hens were 29 weeks of age, at which point twelve hens were randomly selected from both groups. These animals were used for blood collection, and after euthanization by cervical dislocation, they were carcassed and sampled for further laboratory tests.

\subsection{Production Parameters Screening}

Daily egg production, egg weight and feed intake were recorded daily throughout the trial. The feed conversation ratio (FCR) was expressed as each kilogram of feed consumed per kilogram of egg produced by the batch. The laying rate (\%) was calculated as the number of laid eggs to number of laying hens by batch per day. For the presented experiment, the number of eggs produced and the consumption of feed per animal, egg weight $(\mathrm{g})$, FCR, and laying rate in week 29 were recorded.

\subsection{Egg Shell Analysis}

The mineral composition of the eggshells was analyzed according to the procedure of Skalická et al. [29]. Eggshell samples were immediately frozen and stored at $-20{ }^{\circ} \mathrm{C}$ until they were analyzed. The samples were digested in a MLS 1200 MEGA (Milestone Microwave Laboratory System, Shelton, CT, USA) microwave oven using a mixture of $5 \mathrm{~mL} \mathrm{HNO} 3$ and $1 \mathrm{~mL} \mathrm{HCl}$ per $1 \mathrm{~g}$ of sample. The digested samples were analyzed for the presence of $\mathrm{Ca}, \mathrm{Mg}, \mathrm{K}, \mathrm{Na}, \mathrm{Cu}, \mathrm{Zn}$, and $\mathrm{Mn}$ using an atomic absorption spectrometer (Unicam Solar 939, Cambridge, UK). The phosphorus (P) content in the eggshell samples was determined spectrophotometrically [30]. A total of 18 egg samples from the $\mathrm{C}$ and $\mathrm{H}$ experimental groups were collected in week 29 and were subjected to eggshell analysis. Eggshell analysis was performed in triplicate and was expressed as the mean and the standard deviation

\subsection{Homogenization of Cecum and Isolation of Total RNA of IgA, IGF-2 and MUC-2 Genes}

Tissue samples (cecum) were cut into approximately $20 \mathrm{mg}$ pieces and were immediately placed in RNA Later solution (Qiagen, West Sussex, UK). They were stored at $-70^{\circ} \mathrm{C}$ before RNA purification, as described in Karaffová et al. [31]. A total of 12 cecum samples from each experimental group of laying hens were collected after slaughtering and, the samples were subjected to analysis.

\subsection{Relative Expression of IgA, IGF-2 and MUC-2 Genes in Quantitative Real-Time PCR (qRT-PCR)}

The mRNA levels of selected genes were determined. In addition, the mRNA relative expression for reference gene coding GAPDH (glyceraldehyde-3-phosphate dehydrogenase) was selected based on expression stability using BestKeeper software (Pfaffl, Germany). The primer sequences, optimal annealing temperature, and time for each primer used for qRT-PCR are listed in Table 2. All primer sets allowed DNA amplification efficiencies between $94 \%$ and $100 \%$.

The amplification and detection of specific products were performed using the CFX 96 RT system (Bio-Rad, Hercules, CA, USA) and the Maxima SYBR Green qPCR Master Mix (Thermo Scientific, Waltham, MA, USA). Subsequent qRT-PCR to detect the relative expression of mRNA in the selected parameters was conducted over 38 cycles under the following conditions: initial denaturation at $94{ }^{\circ} \mathrm{C}$ for $3 \mathrm{~min}$, subsequent denaturation at $93{ }^{\circ} \mathrm{C}$ for $45 \mathrm{~s}$, and annealing (Table 2) and extension for $10 \mathrm{~min}$ at $72^{\circ} \mathrm{C}$. A melting curve from $50{ }^{\circ} \mathrm{C}$ to $95^{\circ} \mathrm{C}$ with readings at every $0.5^{\circ} \mathrm{C}$ was produced for each individual qRT- 
PCR plate. Analysis was performed after every run to ensure a single amplified product for each reaction. All reactions for real-time PCR were done in duplicate, and the mean values of the duplicates were used for subsequent analysis. We also confirmed that the efficiency of the target gene amplification including GAPDH was essentially $100 \%$ in the exponential phase of the reaction, where the quantification cycle $(\mathrm{Cq})$ was calculated. The $\mathrm{Cq}$ values of the studied genes were normalised to an average $\mathrm{Cq}$ value of the reference genes $(\Delta \mathrm{Cq})$, and the relative expression of each gene was calculated as $2^{-\Delta \mathrm{Cq}}$.

Table 2. List of primers used in RT-PCR for IgA, MUC-2, and IGF-2 mRNA detection in layer hens.

\begin{tabular}{cccc}
\hline Primer & Sequence $5^{\prime}-\mathbf{3}^{\prime}$ & $\begin{array}{c}\text { Annealing/Temperature } \\
\text { Time }\end{array}$ & References \\
\hline IgA For & GTCACCGTCACCTGGACTACA & $55^{\circ} \mathrm{C} / 30 \mathrm{~s}$ & {$[32]$} \\
IgA Rev & ACCGATGGTCTCCTTCACATC & & \\
Muc 2 For & GCTGATTGTCACTCACGCCTT & $54^{\circ} \mathrm{C} / 1 \mathrm{~min}$ & {$[33]$} \\
Muc 2 Rev & ATCTGCCTGAATCACAGGTGC & & \\
IGF-2 For & CTCTGCTGGAAACCTACTGT & $55^{\circ} \mathrm{C} / 30 \mathrm{~s}$ & {$[34]$} \\
IGF-2 Rev & GAGTACTTGGCATGAGATGG & & \\
GAPDH For & CCTGCATCTGCCCATTT & $59^{\circ} \mathrm{C} / 30 \mathrm{~s}$ & {$[35]$} \\
GAPDH Rev & GGCACGCCATCACTATC & & \\
\hline
\end{tabular}

\subsection{Phagocyte Activity Testing}

The percentage of active phagocytes as well as the engulfing capacity of the phagocytes was determined using a commercial Phagotest ${ }^{\circledR}$ assay (Glycotope Biotechnology, Heidelberg, Germany). The test was performed according to the manufacturer's instructions and were performed using fresh heparinized blood [36].

\subsection{Identification of Lymphocyte Subpopulations}

For the identification of selected lymphocyte subpopulations, mononuclear cells were isolated from $600 \mu \mathrm{L}$ of heparinized blood diluted 1:1 with phosphate buffer saline (PBS; MP Biomedicals, Illkirch, France), which was carefully overlaid on the $2.5 \mathrm{~mL}$ of separation solution LSM 1077 (PAA Laboratories GmbH, Pashing, Austria). Mononuclear cells were obtained from the interphase between the separation solution and the plasma after centrifugation at $600 \times g$ for $30 \mathrm{~min}$. The obtained cells were washed twice with PBS through centrifugation at $250 \times g$ for $5 \mathrm{~min}$. The concentration of the mononuclears was determined after staining with Türck's solution in a Bürker chamber and was adjusted to $5 \times 10^{5}$ cells in $50 \mu \mathrm{L}$.

To identify selected subpopulations of lymphocytes, direct immunostaining using two combinations of conjugated mouse anti-chicken monoclonal antibodies (Southern Biotech, Birmingham, AL, USA): CD4/CD8a/CD45 and CD3/IgM was used according to the specifications given in Table 3. The cells were incubated with antibodies for $20 \mathrm{~min}$ in the dark at laboratory temperature. The cells were then washed twice with $1 \mathrm{~mL}$ PBS $(250 \times g$ for $5 \mathrm{~min}$ ) and were resuspended in $100 \mu \mathrm{L}$ of PBS for subsequent cytometric analysis.

Table 3. Specification and amounts of used mouse anti-chicken monoclonal antibodies.

\begin{tabular}{cccccc}
\hline Type & Fluorochrome & Clone & Isotype & Concentration & Amount $\mathbf{5} \times \mathbf{1 0}^{\mathbf{5}}$ cells \\
\hline anti-CD3 & FITC & CT-3 & IgG1 $\mathrm{k}$ & $0.5 \mathrm{mg} \cdot \mathrm{mL}^{-1}$ & $2 \mu \mathrm{L}$ \\
anti-CD4 & FITC & CT-4 & IgG1, $\mathrm{k}$ & $0.5 \mathrm{mg} \cdot \mathrm{mL}^{-1}$ & $2 \mu \mathrm{L}$ \\
anti-CD8a & R-PE & CT-8 & IgG1, $\mathrm{k}$ & $0.1 \mathrm{mg} \cdot \mathrm{mL}^{-1}$ & $1 \mu \mathrm{L}$ \\
anti-CD45 & APC & LT-40 & IgM, $\mathrm{k}$ & $0.1 \mathrm{mg} \cdot \mathrm{mL}^{-1}$ & $5 \mu \mathrm{L}$ \\
anti-IgM & R-PE & M-1 & IgG2b $\kappa$ & $0.1 \mathrm{mg} \cdot \mathrm{mL}^{-1}$ & $1 \mu \mathrm{L}$ \\
\hline
\end{tabular}

\subsection{Flow Cytometric Analysis}

Phagocytic activity analysis as well as the identification of lymphocyte subpopulations was performed on a six colour BD FACSCanto ${ }^{\text {TM }}$ flow cytometer (Becton Dickinson 
Biosciences, San Diego, CA, USA) using BD FACS Diva ${ }^{\mathrm{TM}}$ software. The position of the analysed cells was gated in FSC vs. SSC dot plots. Granulocytes and monocytes were gated for phagocytic activity analysis. Bacterial aggregates were excluded from further analysis based on the low DNA content in the red fluorescence histogram (FL-2). The percentage of active phagocytes and the mean fluorescence intensity were determined in the green fluorescence histogram (FL-1).

Gated lymphocytes were used for the identification of lymphocyte subpopulations, while contaminating chicken thrombocytes were differentiated from lymphocytes based on their higher side scatter profiles [37]. CD3+ lymphocytes represent $\mathrm{T}$ lymphocytes, and $\mathrm{IgM}+$ cells are a subpopulation of $\mathrm{B}$ lymphocytes. CD4+CD8a- and CD4+CD8a low $/ \mathrm{mid}$ subpopulations were counted together as a representative of the $T$ helper lymphocytes. The CD4-CD8a+ subpopulation was evaluated as T cytotoxic cells. Proportions of lymphocytes are expressed in percentage.

\subsection{Intestinal Bacteria Analysis}

In the contents of the small intestine and caecum were analysed to determine the number of lactic acid bacteria and enterobacteria using the plate count method after a 10-fold dilution in saline. MRS agar plates (HiMedia, Karnataka, India) that had been anaerobically incubated (GasPak system, Becton Dickinson, San Diego, CA, USA) for $48 \mathrm{~h}$ at $37^{\circ} \mathrm{C}$ were used to determine the number of lactic acid bacteria. Enterobacteria were counted on Endo agar plates (HiMedia, Karnataka, India) after a $24 \mathrm{~h}$ incubation period at $37^{\circ} \mathrm{C}$ under aerobic conditions. The bacterial counts are expressed in $\log _{10}$ of colony forming units per gram of content $\left(\log _{10} \mathrm{cfu} \cdot \mathrm{g}^{-1}\right) \pm$ standard deviation.

\subsection{Statistical Analysis}

The results obtained in this experiment were expressed as the means of the relevant units and the standard deviation (SD). Data were evaluated using the unpaired Student's T-test with the statistical software GraphPad Prism 8.3 (GraphPad Software, San Diego, CA, USA). A significance level of $p<0.05$ was set prior to the data analysis.

\section{Results}

\subsection{Production Parameters}

Dietary supplementation with $0.5 \%$ HS additives had a significant effect on the following laying performance variables recorded in week 29: laying rate, daily egg mass, egg weight, and FCR, compared to the control group $(p<0.05)$ (Table 4).

Table 4. The results of layer production indices in week 29 (means $\pm \mathrm{SD}$ ).

\begin{tabular}{cccc}
\hline Variable & C & H & $p$-Value \\
\hline Laying rate, $\%$ & $84.29 \pm 7.87^{\mathrm{b}}$ & $95.91 \pm 6.98^{\mathrm{a}}$ & 0.013 \\
Daily egg mass, g/hen/day & $47.50 \pm 4.37^{\mathrm{b}}$ & $57.06 \pm 4.05^{\mathrm{a}}$ & 0.001 \\
Egg weight, g & $56.36 \pm 0.39^{\mathrm{b}}$ & $59.50 \pm 0.67^{\mathrm{a}}$ & $<0.001$ \\
Feed consumption, g/hen/day & $115.86 \pm 2.27$ & $116.00 \pm 1.53$ & 0.892 \\
Feed conversion ratio & $2.46 \pm 0.22^{\mathrm{b}}$ & $2.04 \pm 0.14^{\mathrm{a}}$ & 0.001 \\
\hline
\end{tabular}

C: control group; H: layers fed a diet enriched with supplementation of $0.5 \%$ HS. ${ }^{a, b}$ Means not sharing the same superscripts in the same row are significantly different.

\subsection{Eggshell Mineral Analysis}

When analyzing experimental eggshell samples, higher concentrations of minerals were determined, compared to the results from the control group. A significant increase was observed in the contents of copper $(p<0.001)$, phosphorus $(p<0.01)$, calcium, manganese, and zinc $(p<0.05)$ (Table 5). 
Table 5. The results of eggshell mineral analysis (means \pm SD).

\begin{tabular}{cccc}
\hline Variable & $\mathbf{C}$ & $\mathbf{H}$ & $p$-Value \\
\hline Calcium, $\mathrm{g} \cdot \mathrm{kg}^{-1}$ & $57.66 \pm 0.27^{\mathrm{b}}$ & $59.22 \pm 1.09^{\mathrm{a}}$ & 0.014 \\
Magnesium, $\mathrm{g} \cdot \mathrm{kg}^{-1}$ & $4.40 \pm 0.25$ & $4.67 \pm 0.46$ & 0.281 \\
Phosphorus, $\mathrm{g} \cdot \mathrm{kg}^{-1}$ & $2.69 \pm 0.35^{\mathrm{b}}$ & $4.77 \pm 1.14^{\mathrm{a}}$ & 0.005 \\
Sodium, $\mathrm{g} \cdot \mathrm{kg}^{-1}$ & $0.96 \pm 0.04$ & $0.91 \pm 0.09$ & 0.276 \\
Potassium, $\mathrm{g} \cdot \mathrm{kg}^{-1}$ & $0.61 \pm 0.06$ & $0.55 \pm 0.10$ & 0.306 \\
Copper, $\mathrm{mg} \cdot \mathrm{kg}^{-1}$ & $36.68 \pm 4.22^{\mathrm{b}}$ & $46.69 \pm 1.90^{\mathrm{a}}$ & 0.001 \\
Zinc, $\mathrm{mg} \cdot \mathrm{kg}^{-1}$ & $21.14 \pm 6.59^{\mathrm{b}}$ & $31.96 \pm 8.09^{\mathrm{a}}$ & 0.049 \\
Manganese, $\mathrm{mg} \cdot \mathrm{kg}^{-1}$ & $26.36 \pm 2.09^{\mathrm{b}}$ & $30.09 \pm 1.57^{\mathrm{a}}$ & 0.013
\end{tabular}

C: control group; H: layers fed a diet enriched with supplementation of $0.5 \%$ HS. ${ }^{a, b}$ Means not sharing the same superscripts in the same row are significantly different.

\subsection{The Relative Expression of Selected Genes}

The relative expression for the IgA gene was significantly upregulated in the humic group compared to the control group $(p<0.05)$. Similarly, MUC-2 gene expression was upregulated, but it was not significant in $\mathrm{H}$ group, compared to the control. On the contrary, the relative expression for the IGF-2 gene was not influenced by the addition of HS (Figure 1).

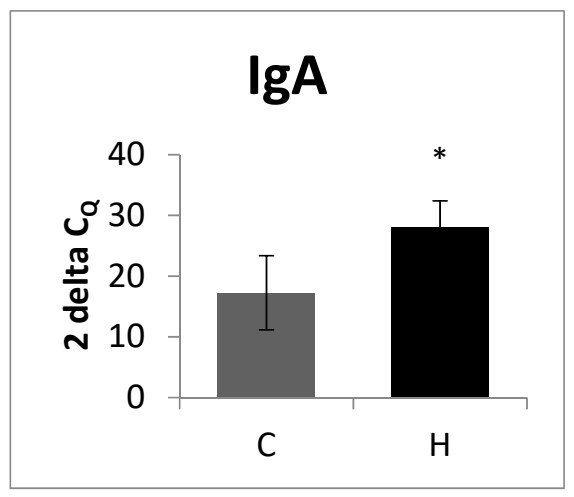

(a)



(b)

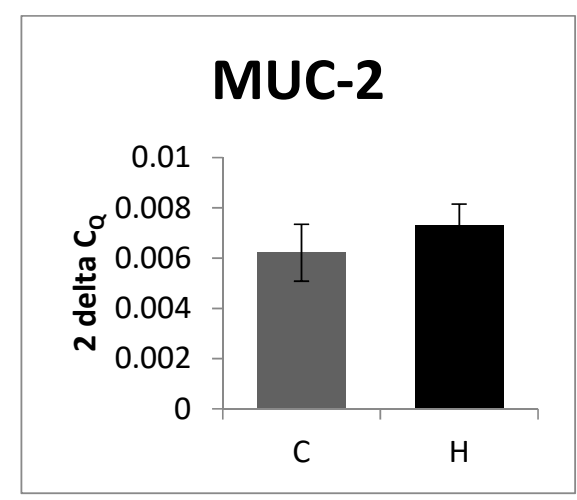

(c)

Figure 1. Relative expression of IgA (a), IGF-2 (b), and MUC-2 (c) genes in cecum of laying hens treated with $0.5 \%$ HS. Results at each time point are the median of $2^{-\Delta C q}$. C: control group; H: layers fed a diet enriched with supplementation of $0.5 \%$ HS. Columns marked with stars are significantly different from control: ${ }^{*} p<0.05$.

\subsection{Cellular Immune Response}

In testing the effect of HS on cellular immunity, the phagocyte activity, which represents the innate component of the immune response and the representation of the selected lymphocyte population in the blood as a parameter of the acquired immune response, was monitored.

The addition of HS to the feed of laying hens significantly increased the percentage of active phagocytes as well as the engulfing capacity (Figure 2).

The results from the phenotyping of the blood lymphocytes showed that HS stimulate the differentiation of the B lymphocytes when a significantly higher proportion of $\operatorname{IgM}+$ lymphocytes was recorded (Figure 3a). This finding is also supported by the increased expression of IgA genes in the gut. In contrast, the proportion of total T cells (CD3+) was thus reduced (Figure $3 b$ ). There was no statistically significant effect of HS on the T cell subpopulations; either CD4+ (Figure 3c) or CD4-CD8+ (Figure 3d) was observed. 


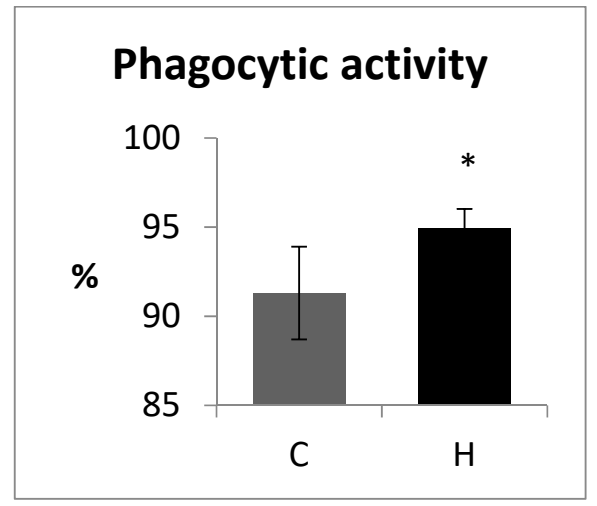

(a)

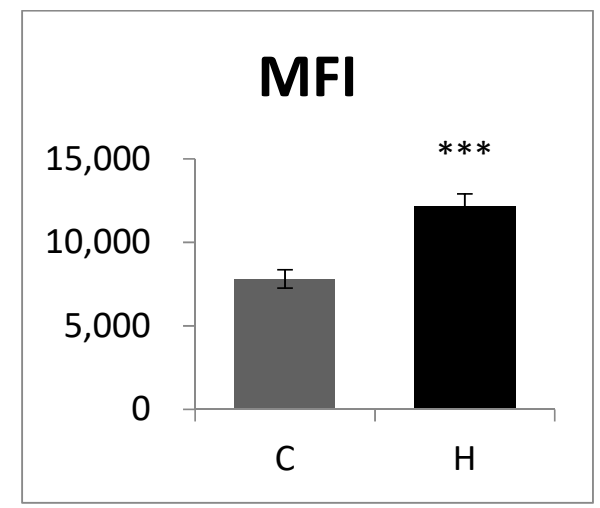

(b)

Figure 2. Influence of $0.5 \%$ HS on phagocyte activity in layer blood evaluated as (a) percentage of active phagocytes (phagocytic activity) and (b) engulfing capacity of the phagocytes (expressed as mean fluorescence intensity-MFI). C: control group; $\mathrm{H}$ : layers fed a diet enriched with supplementation of $0.5 \% \mathrm{HS}$. Columns marked with stars are significantly different from control: ${ }^{*} p<0.05 ;{ }^{* * *} p<0.001$.

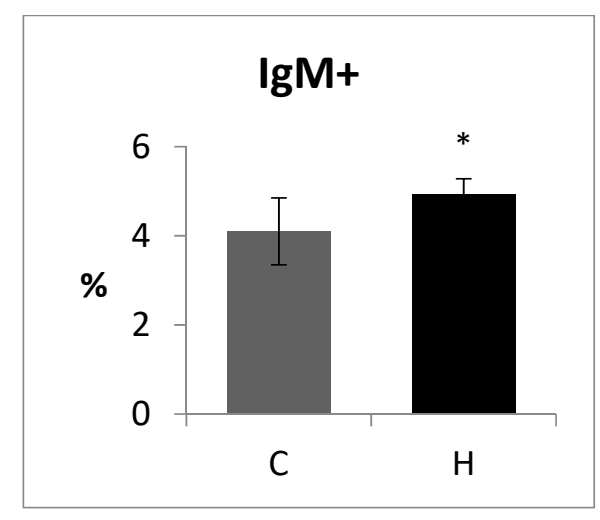

(a)

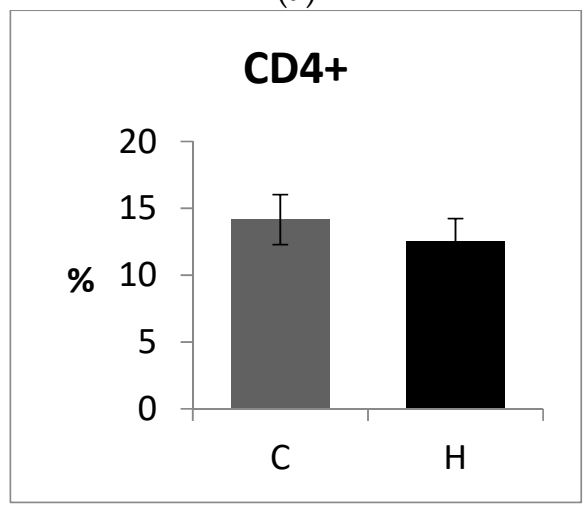

(c)

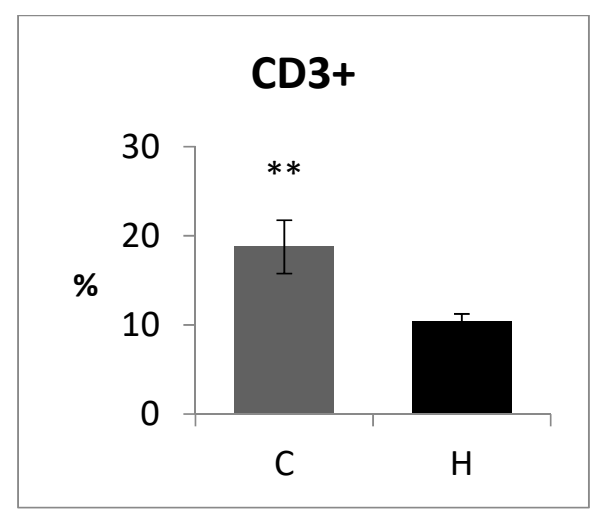

(b)

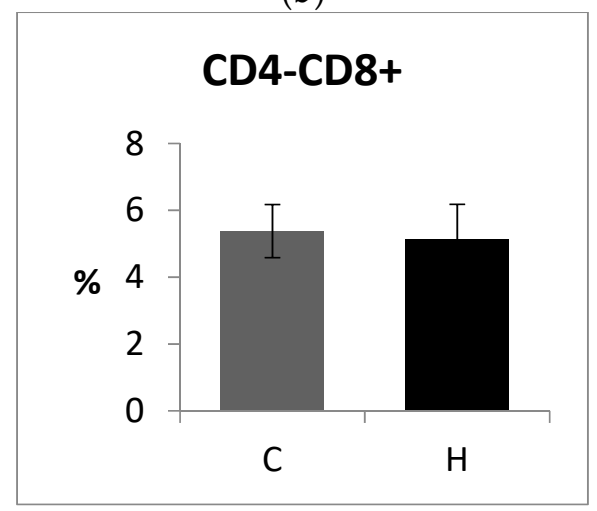

(d)

Figure 3. Percentage of (a) IgM+, (b) CD3+, (c) CD4+, and (d) CD4-CD8+ lymphocytes in the blood of laying hens receiving $0.5 \%$ HS. C: control group; H: layers fed a diet enriched with supplementation of $0.5 \%$ HS. Columns marked with stars are significantly different from control: ${ }^{*} p<0.05 ;{ }^{* *} p<0.01$.

\subsection{Intestinal Microbiota}

The effect of HS on the intestinal microbiota was evaluated on the basis of the presence of lactic acid bacteria and enterobacteria in the contents of the small intestine and the cecum. The results showed that the application of HS did not affect the numbers of LAB in any of the monitored sections of the intestine (Figure 4a) but did significantly increase the numbers of enterobacteria, both in the small intestine and in the cecum (Figure 4b). 


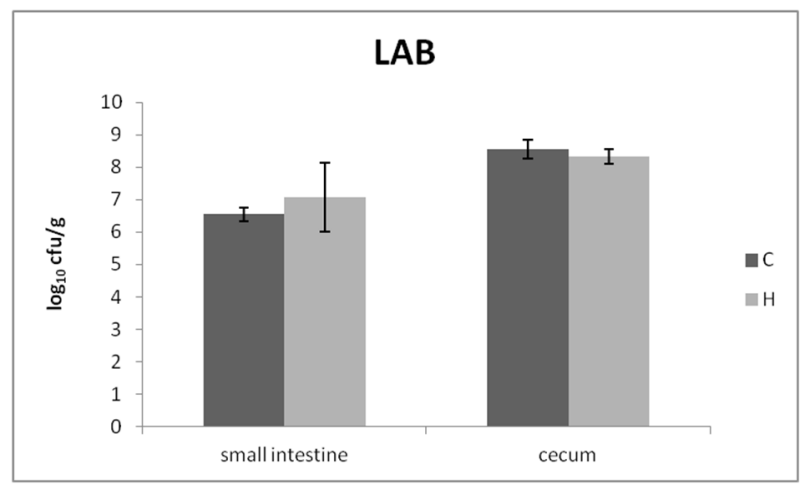

(a)

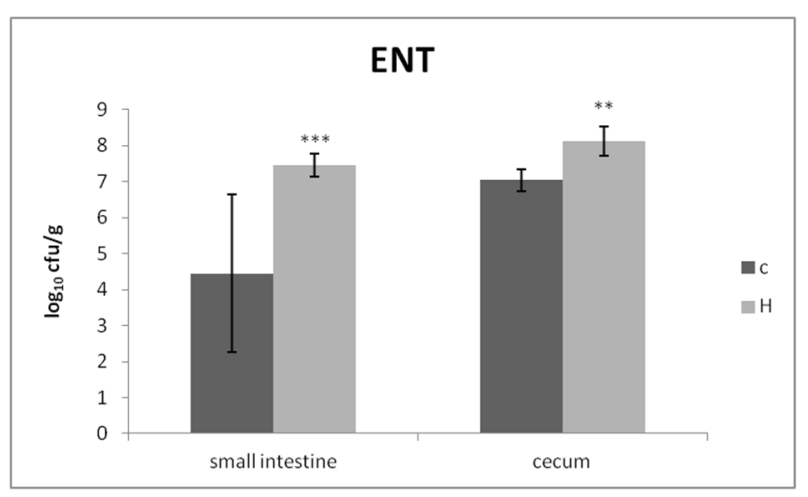

(b)

Figure 4. The influence of $0.5 \%$ HS on the counts of (a) lactic acid bacteria (LAB) and (b) enterobacteria (ENT) in the contents of the small intestine and the caecum. C: control group; H: layers fed a diet enriched with supplementation of $0.5 \%$ HS. Columns marked with stars are significantly different from control: ${ }^{* *} p<0.01 ;{ }^{* * *} p<0.001$.

\section{Discussion}

HS are a heterogeneous group of natural organic molecules that are part of soil and water organic matter. These are substances with a whole range of positive health effects. In our work, we focused on the effect of the administration of HS on cellular immune response, the protection of intestine in poultry as well as on specific productive parameters.

Dietary supplementation with HS additives had a significant effect on the laying rate, daily egg mass, egg weight, and feed conversion, which indicate the ability of HS to stabilize the intestinal microbiota, thus ensuring improved nutrient utilization in feed [38,39]. These findings are consistent with our results. Similarly, the beneficial effect of feeding humates in a $0.25 \%$ concentration during broiler fattening was observed in Kocabagli et al. [40]. In this study, the supplementation of humates at the time of fattening (day 22-42) significantly improved feed conversion as well as increased the body weight of the broilers compared to the control group and broilers supplemented with HS over the time period of 0-21 days. However, some studies suggest conflicting results. For example, a study in 2006 by Rath et al. [41] reported that HS in 0.5 and $1 \%$ concentrations have a negative effect on the broiler growth performance.

The importance of minerals on eggshell quality is unquestionable. The eggshell consists of $94.85 \%$ of minerals, of which calcium carbonate, magnesium carbonate, and calcium phosphate have the highest proportions. Therefore, phosphorus and calcium are the most important elements for the formation of the outer shell of an egg. In addition, eggshell contains $4.15 \%$ organic matter and water in a proportion of less than $2 \%$ [42]. According to the achieved results, the increase in the mineral content in the eggshell was favorably influenced by the supplementationHS in the diet of laying hens. Moreover, the administration of $0.5 \%$ HS product (Humac Natur AFM) contains up to $42,278 \mathrm{mg} \cdot \mathrm{kg}^{-1}$ of calcium and $5111 \mathrm{mg} \cdot \mathrm{kg}^{-1}$ of magnesium [20]. The increase in the mineral content may also be related to the relationships among the elements or the HS components. The absorption of calcium, manganese, iron, and phosphorus decreases with higher levels of HS in the diet [41]. Reasons for this could be the chelating effects of HS that are influenced by their large number of carboxylic acid side chains [43]. Moreover, HS have the ability to bind to elements from the environment and can also release these elements after changes in external conditions. This property, in the case of action in the gastrointestinal tract, affects the eggshell quality [44]. Interestingly, the results obtained by Ergin et al. [45] suggested that addition of humic acids $\left(30 \mathrm{mg} \cdot \mathrm{kg}^{-1}\right.$ diet) enhanced eggshell strength without affecting feed efficiency and egg production. Likewise, Tancho [46] concluded that eggshell thickness was increased in hens fed with humates at levels of 1 and $2 \mathrm{~g} \cdot \mathrm{kg}^{-1}$.

In order to achieve maximum production, good health is essential, which is conditioned by the state of the immune system. Generally, the largest immune organ is the 
gut-associated lymphoid tissue (GALT), and the first line of defense is non-specific barriers, including mucin and other components. The mucus layer also acts as a medium for molecule transport between luminal content and enterocytes. We observed a nonsignificant increase in relative mRNA expression for MUC-2 but a significant increase in IgA gene expression, which is consistent with the finding that humic acids may aid in the formation of a protective film on the mucus epithelium of the gastrointestinal tract, which protects against infectious agents and toxins, thereby also improving animal feed utilization [23]. In addition, the main function of IgA is to neutralize antigens on the mucosal surfaces. On the other hand, our results showed that HS in a $0.5 \%$ concentration did not affect IGF-2 gene expression. This fact is interesting from the point of view that IGF-2 plays a very important role in the postnatal development of the organism and mediates most of growth effects; thus, it has significant effects on the skeletal and muscular systems. In our previous study, we observed the same effect of $0.8 \%$ HS on the relative expression of IGF-2 in broilers [20]. On the contrary, Weber et al. [47] reported an increase of serum IGF-1 in pigs treated with Menefee humate $(0.25 \%$ of humic acid). In tune with previous studies and our knowledge, we suppose that the influence of HS on the expression of growth factors is dependent on the concentration of the HS that is administered.

As in our previous study, where we administered $0.8 \%$ HS to broilers, even now, after the application of $0.5 \%$ HS to laying hens, we observed a significant increase in both the percentage of active phagocytes and their engulfing capacity [20]. Sanmiguel and Rondón [48] suggested that this effect on phagocytes is time dependent. They administered $0.1 \%$ and $0.2 \%$ HS to laying hens and found that the phagocytic index was elevated after 8 and 30 days of application, but subsequently (on 60th day), phagocytic index significantly decreased and was lower than in the control group. Although the mode of action of HS on phagocytosis has not been fully explained, studies with human neutrophils have shown that HS stimulate their adhesion abilities and superoxide production, and they are able to mediate intracellular signal transduction leading to NF- $\mathrm{KB}$ induction, which is crucial for the transcription of many proinflammatory genes (e.g., IL-2, IL-8, MCP-1, TNF- $\alpha$, GMCSF) [49]. Similarly, Riede et al. [50] confirmed the stimulatory effect of HS on the oxidative burst of human neutrophils but without activating chemotaxis. The authors hypothesize that HS contain chemical structures that can be recognized by the neutrophils and can activate them.

Because works on the effect of HS on individual lymphocyte subpopulations are rare, we examined the proportions of IgM+ lymphocytes, T lymphocytes, and T helper and $\mathrm{T}$ cytotoxic cells in our study. According to a study by Luthala [51], in chickens, the CD8 $\alpha \alpha$ homodimer may be expressed on peripheral CD4+ cells, but expression of the $\mathrm{CD} 8 \alpha \beta$ heterodimer only occurs on cytotoxic T cells. In this type of expression, chicken and mammalian lymphocytes differ significantly. Functionally, a subpopulation of CD4+CD8+ $\mathrm{T}$ cells in chickens is reported as T helper and/or regulatory lymphocytes. These findings were confirmed by both the expression of the CD25 molecule (IL-2 receptor-typical for regulatory cells), which was detected on part of the cells from the CD4+CD8- as well as the CD4+CD8+ subpopulations and by their cytokine profiles [52]. For these reasons, even in our study, CD4+CD8+ lymphocytes with low and medium expression of the CD8 molecule were included in the $\mathrm{T}$ helper cell subpopulation.

We found that the addition of $0.5 \%$ HS to the feed of laying hens increased the proportion of IgM+ lymphocytes and thus decreased the proportion of $\mathrm{T}$ lymphocytes, while the proportion of $\mathrm{T}$ helper and $\mathrm{T}$ cytotoxic cells was not affected. The increased percentage of the IgM+ lymphocyte subpopulation is consistent with the finding of increased gene expression for IgA in the gut. Zhang et al. [38] (2020) also noted significantly elevated serum IgM as well as IgG levels after the administration of 0.1 and $0.5 \%$ HS to laying hens, which confirms the activation of B cells. Similarly, Salah et al. [53] reported an increase in the serum gamma globulin fraction containing most of immunoglobulins after 5 days of humic acid application to broiler chickens. Interestingly, when we administered $0.8 \%$ HS to broiler chickens from day 11 of life to the end of fattening (day 38) in the previous 
experiment, we observed a significantly higher percentage of $\mathrm{T}$ cells as well as $\mathrm{T}$ helper cells (CD4+), but the gene expression for IgA was not affected [20]. Based on the above results, we assume that the obtained cellular immune response depends not only on the used concentration and the duration of HS application but also depends on the category of poultry to which they are applied.

The exact mechanism of action by which HS affect specific subpopulations of immune cells has not yet been elucidated, but their effect on cytokine production has been confirmed. Vetvicka et al. [54] reported a significant increase in the production of IL-5 and IL-6 in mice intraperitoneally treated with HS. These cytokines stimulate B lymphocyte differentiation and growth and increase the secretion of immunoglobulins. The theory that explains the immunomodulatory potential of HS is that humates are able to form complexes with carbohydrates, amino acids, and peptides. Currently such complexes are considered to be biologically active and can subsequently bind to the surface of T lymphocytes and NK cells, thereby regulating their functions, including cytokine production. Subsequently, cytokines influence further immune reactions $[50,55]$.

Regarding the effect of HS on the intestinal microbiota, the results of different authors vary considerably. While some have reported a decrease in enterobacteria [20,39], others have observed an increase [56]. Similarly, different results were observed for other bacterial species. In our case, there was an increase in the numbers of $E$. coli in the intestine and in the cecum, but the number of lactic acid bacteria was not affected. Such a trend can be considered as negative. These results are consistent with in vitro microbiological tests that have shown that various species of Lactobacillus spp. and different strains of E. coli also respond differently to HS (unpublished data). Similar results were obtained by Buzoleva and Sidorenko [57], who found that the multiplication of enterobacteria in the presence of HS depends on both the type of bacterium and the HS composition.

\section{Conclusions}

We can conclude that the addition of $0.5 \%$ HS to laying hen feed had a positive effect on laying rate, daily egg mass, egg weight, feed conversion, and eggshell quality and also had an immunostimulatory effect manifested by the increasing activity of the phagocytes and the $\mathrm{B}$ cell immune response. On the other hand, there was an observed increase in the number of enterobacteria in the intestinal contents, and the proportion of $\mathrm{T}$ lymphocytes in the blood was significantly reduced. The presented results confirm that HS can be used for the improvement of egg production and quality and for activation of phagocytosis and specific antibody immunity, but their influence on the intestinal microbiota will need to be further studied with respect to a wider range of microbial species inhabiting the digestive tract of laying hens.

Author Contributions: D.M., investigation, formal analysis, writing; V.K., investigation, formal analysis, writing; B.S., investigation, writing; P.N. and J.K., investigation; M.B., animal experiment management and investigation; A.M. and L.B., investigation; J.N. and J.M., supervision; S.M., conceptualization and resources. All authors have read and agreed to the published version of the manuscript.

Funding: This research was funded by the Operational Programme Integrated Infrastructure within the project Demand-driven research for the sustainable and innovative food, Drive4SIFood 313011V336, co-financed by the European Regional Development Fund.

Institutional Review Board Statement: The study was conducted according to the European directive 2010/63/EU on the protection of animals used for scientific purposes and was approved by the Ethical Committee of the University of Veterinary Medicine and Pharmacy in Košice and the State Veterinary and Food Administration of the Slovak Republic, approved by the experimental protocol number 3040/14-221 in December 2014.

Informed Consent Statement: Not applicable.

Data Availability Statement: The data presented in this study are available upon request from the corresponding author. 
Acknowledgments: The authors gratefully acknowledge Humac Ltd., Košice, Slovakia, for providing humic substances for the experiment. A special thanks to Salonee Udani, an English native speaker from London, who is a student at the University of Veterinary Medicine and Pharmacy in Košice (Slovakia), for English proofreading.

Conflicts of Interest: The authors state that there are no conflicts of interest regarding the publication of this article.

\section{References}

1. Lin, P.; Xu, C.; Xing, W.; Sun, L.; Kaplan, D.I.; Fujitake, N.; Yeager, C.M.; Schwehr, K.A.; Santschi, P.H. Radionuclide uptake by colloidal and particulate humic acids obtained from 14 soils collected worldwide. Sci. Rep. 2018, 8, 4795. [CrossRef] [PubMed]

2. Mihajlović, V.; Tomić, T.; Tubić, A.; Jazić, J.M.; Tubmas, I.I.; Sunjka, D.; Lacić, S.; Teodorović, I. The impact of humic acid on toxicity of individual herbicides and their mixtures to aquatic macrophytes. Environ. Sci. Pollut. Res. 2019, 26, $23571-23582$. [CrossRef] [PubMed]

3. Zhang, S.; Wen, J.; Hu, Y.; Fang, Y.; Zhang, H.; Xing, L.; Wang, Y.; Zeng, G. Humic substances from green waste compost: An effective washing agent for heavy metal (Cd, Ni) removal from contaminated sediments. J. Hazard. Mater. 2019, 366, 210-218. [CrossRef] [PubMed]

4. Volkov, I.V.; Polyakov, E.V. Interaction of humic acids with microelements/radionuclides in sorption systems. Radiochemistry 2020, 62, 141-160. [CrossRef]

5. Maruf, M.T.; Rasul, G.A.M. Influence of humic acid and sulfur on the bioavailability of some micronutrients in calcareous soils. Plant Arch. 2019, 19, 1785-1794.

6. Edmonds, M.S.; Moreland, J.S. Effect of supplemental humic and butyric acid on performance and mortality in broilers raised under various environmental conditions. J. Appl. Poult. Res. 2014, 23, 260-267. [CrossRef]

7. Arif, M.; Alagawany, M.; Abd El-Hack, M.E.; Saeed, M.; Arain, M.A.; Elnesr, S.S. Humic acid as a feed additive in poultry diets: A review. Iran. J. Vet. Res. 2019, 20,167-172. [PubMed]

8. van Rensburg, C.E. The Antiinflammatory properties of humic substances: A mini review. Phytother. Res. 2015, 29, 791-795. [CrossRef]

9. Marcinčáková, D.; Mačanga, J.; Nagy, J.; Marcinčák, S.; Popelka, P.; Vašková, J.; Jad'uttová, I.; Mellen, M. Effect of supplementation of the diet with humic acids on growth performance and carcass yield of broilers. Folia Vet. 2015, 59, $165-168$.

10. Domínguez-Negrete, A.; Gómez-Rosales, S.; Angeles, M.d.L.; López-Hernández, L.H.; Reis-de Souza, T.C.; López-García, Y.; Zavala-Franco, A.; Téllez-Isaias, G. Effect of the addition of humic substances as growth promoter in broiler chickens under two feeding regimens. Animals 2019, 9, 1101. [CrossRef]

11. Semjon, B.; Marcinčáková, D.; Koréneková, B.; Bartkovský, M.; Nagy, J.; Turek, P.; Marcinčák, S. Multiple factorial analysis of physicochemical and organoleptic properties of breast and thigh meat of broilers fed a diet supplemented with humic substances. Poult. Sci. 2020, 99, 1750-1760. [CrossRef]

12. Hudák, M.; Semjon, B.; Marcinčáková, D.; Bujňák, L.; Na', P.; Koréneková, B.; Nagy, J.; Bartkovský, M.; Marcinčák, S. Effect of Broilers Chicken Diet Supplementation with Natural and Acidified Humic Substances on Quality of Produced Breast Meat. Animals 2021, 11, 1087. [CrossRef]

13. Kulshreshtha, G.; Hincke, M.T.; Prithiviraj, B.; Critchley, A. A review of the varied uses of macroalgae as dietary supplements in selected poultry with special reference to laying Hen and broiler chickens. J. Mar. Sci. Eng. 2020, 8, 536. [CrossRef]

14. Hahn, J.; Dehghan, M.; Drouin-Chartier, J.P.; Mentz, R.J.; Jneid, H.; Virani, S.S.; Wilson Tang, W.H.; Krittanawong, C. Egg consumption and risk of cardiovascular disease: A critical review. Curr. Emerg. Hosp. Med. Rep. 2021, 9, 1-13. [CrossRef]

15. Wan, Y.; Ma, R.; Khalid, A.; Chai, L.; Qi, R.; Liu, W.; Li, J.; Li, Y.; Zhan, K. Effect of the pellet and mash feed forms on the productive performance, egg quality, nutrient metabolism, and intestinal morphology of two laying hen breeds. Animals 2021, 11, 701. [CrossRef]

16. Wang, J.; Yue, H.; Wu, S.; Zhang, H.; Qi, G. Nutritional modulation of health, egg quality and environmental pollution of the layers. Anim. Nutr. 2017, 3, 91-96. [CrossRef]

17. Arafat, R.Y.; Khan, S.H.; Abbas, G.; Iqbal, J. Effect of dietary humic acid via drinking water on the performance and egg quality of commercial layers. Am. J. Life Sci. 2015, 3, 26-30.

18. Vlčková, J.; Tůmová, E.; Míková, K.; Englmaierová, M.; Okrouhlá, M.; Chodová, D. Changes in the quality of eggs during storage depending on the housing system and the age of hens. Poult. Sci. 2019, 98, 6187-6193. [CrossRef] [PubMed]

19. Nagaraju, R.; Reddy, B.S.; Gloridoss, R.; Suresh, B.N.; Ramesh, C. Effect of dietary supplementation of humic acids on performance of broilers. Indian J. Anim. Sci. 2014, 84, 447-452.

20. Mudroňová, D.; Karaffová, V.; Pešulová, T.; Koščová, J.; Maruščáková, I.C.; Bartkovský, M.; Marcinčáková, D.; Ševčíková, Z.; Marcinčák, S. The effect of humic substances on gut microbiota and immune response of broilers. Food Agric. Immunol. 2020, 31, 137-149. [CrossRef]

21. Hanafy, M.M.; El-Sheikh, A.M.H. The effect of dietary humic acid supplementation on some productive and physiological traits of laying hens. Egypt. Poult. Sci. 2018, 28, 1043-1058. 
22. Arif, M.; Rehman, A.; El-Hack, M.E.A.; Saeed, M.; Khan, F.; Akhtar, M.; Swelum, A.A.; Saadeldin, I.M.; Alowaimer, A.N. Growth, carcass traits, cecal microbial counts, and blood chemistry of meat-type quail fed diets supplemented with humic acid and black cumin seeds. Asian Aust. J. Anim. Sci. 2018, 31, 1930-1938. [CrossRef]

23. Islam, K.; Schuhmacher, A.; Gropp, J. Humic acid substances in animal agriculture. Pak. J. Nutr. 2005, 4, 126-134.

24. Arpášová, H.; Kačániová, M.; Pistová, V.; Gálik, B.; Fik, M.; Hleba, L. Effect of probiotics and humic Aaid on egg production and quality parameters of laying hens eggs. Sci. Pap. Anim. Sci. Biotechnol. 2016, 49, 1-9.

25. Sopoliga, I.; Hreško-Šamudovská, A.; Demeterová, M.; Na', P.; Marcin, A.; Skalická, M. Effect of humic substances on the production parameters of pheasant hens. Acta Fytotech. Zootech. 2016, 19, 11-14. [CrossRef]

26. Lohmann-Breeders Home Page. Available online: https://www.ltz.de/de-wAssets/docs/management-guides/en/Cage/ Brown/LTZ-Management-Guide-LB-Classic-EN.pdf (accessed on 7 June 2021).

27. An Official Website of the European Union. Available online: https://op.europa.eu/en/publication-detail/-/publication/7270 9682-c5e2-42a4-948d-1877344bb582/language-en (accessed on 7 June 2021).

28. Semjon, B.; Bartkovský, M.; Marcinčáková, D.; Klempová, T.; Bujňák, L.; Hudák, M.; Ja'uttová, I.; Čertík, M.; Marcinčák, S. Effect of Solid-State Fermented Wheat Bran Supplemented with Agrimony Extract on Growth Performance, Fatty Acid Profile, and Meat Quality of Broiler Chickens. Animals 2020, 10, 942. [CrossRef] [PubMed]

29. Skalicka, M.; Korenekova, B.; Na', P.; Šály, J. Influence of chromium and cadmium addition on quality of Japanese quail eggs. Acta Vet. Brno. 2008, 77, 503-508. [CrossRef]

30. Associatition of Official Analytical Chemists International. Official Methods of Analysis, 17th ed.; AOAC: Arlington, TX, USA, 2001.

31. Karaffová, V.; Bobíková, K.; Levkut, M.; Revajová, V.; Ševčíková, Z.; Levkut, M. The influence of Farmatan ${ }^{\circledR}$ and Flimabend ${ }^{\circledR}$ on the mucosal immunity of broiler chicken. Poult. Sci. 2019, 98, 1161-1166. [CrossRef]

32. Lammers, A.; Wieland, W.H.; Kruijt, L.; Jansma, A.; Straetemans, T.; Schots, A.; den Hartog, G.; Parmentier, H.K. Successive immunoglobulin and cytokine expression in the small intestine of juvenile chicken. Dev. Comp. Immunol. 2010, 34, 1254-1262. [CrossRef]

33. Smirnov, A.; Tako, E.; Ferket, P.R.; Uni, Z. Mucin gene expression and mucin content in the chicken intestinal goblet cells are affected by in ovo feeding of carbohydrates. Poult Sci. 2006, 85, 669-673. [CrossRef]

34. Mudronová, D.; Karaffová, V.; Košcová, J.; Bartkovský, M.; Marcincáková, D.; Popelka, P.; Klempová, T.; Certík, M.; Macanga, J.; Marcincák, S. Effect of fungal gamma-linolenic acid and beta-carotene containing prefermented feed on immunity and gut of broiler chicken. Poult. Sci. 2018, 97, 4211-4218. [CrossRef]

35. De Boever, S.; Vangestel, C.; De Backer, P.; Croubels, S.; Sys, S.U. Identification and validation of housekeeping genes as internal control for gene expression in an intravenous LPS inflammation model in chickens. Vet. Immunol. Immunopathol. 2008, 122, 312-317. [CrossRef]

36. BD Biosciences Home Page. Available online: https:/ / www.bdbiosciences.com/ds/pm/tds/341060.pdf (accessed on 7 June 2021).

37. Bertram, E.M. Characterization of duck thrombocytes. Res. Vet. Sci. 1998, 64, 267-270. [CrossRef]

38. Zhang, A.R.; Pirzado, S.A.; Liu, G.H.; Chen, Z.M.; Chang, W.H.; Cai, H.Y.; Bryden, W.L.; Zheng, A.J. Dietary supplementation with sodium humate improves egg quality and immune function of laying hens. J. Appl. Anim. Nutr. 2020, 2, 93-99. [CrossRef]

39. Aksu, T.; Bozkurt, A.S. Effect of dietary essential oils and/or humic acids on broiler performance, microbial population of intestinal content and antibody titres in the summer season. Kafkas Univ. Vet. Fak. Derg. 2009, 15, 185-190.

40. Kocabağli, N.; Alp, M.; Acar, N.; Kahraman, R. The effects of dietary humate supplementation on broiler growth and carcass yield. Poult. Sci. 2002, 81, 227-230. [CrossRef]

41. Rath, N.C.; Huff, W.E.; Huff, G.R. Effects of humic acid on broiler chickens. Poult. Sci. 2006, 85, 410-414. [CrossRef]

42. Kiczorowska, B.; Samolinska, W.; Kwiecien, M.; Winiarska-Mieczan, A.; Rusinek-Prystupa, E.; Al-Yasiry, A.R.M. Nutritional value and the content of minerals in eggs produced in large-scale, courtyard and organic systems. J. Elem. 2015, 20, 887-895. [CrossRef]

43. Klöcking, R. Humic substances as potential therapeutics. In Humic Substances in the Global Environment; Senesi, N., Miano, T.M., Eds.; Elsevier: Amsterdam, The Netherlands, 1994; pp. 1245-1257.

44. Hassan, S.B.; Aigbodion, V.S.; Patrick, S.N. Development of polyester/eggshell particulate composites. Tribol. Ind. 2012, 34, 217-225.

45. Ergin, O.; Coskun, I.; Ocak, N.; Erener, G. Effects of dietary humic substances on egg production and egg shell quality of hens after peak laying period. Afr. J. Biotechnol. 2009, 8, 1155-1159.

46. Tancho, A. The Effect of Humic Acid Supplement on Egg Performance and Egg Quality of Laying Hen during 28-47 Weeks of Age. Available online: http:/ / www.kmitl.ac.th/agritech30/example.doc (accessed on 7 June 2021).

47. Weber, T.E.; van Sambeek, D.M.; Gabler, N.K.; Kerr, B.J.; Moreland, S.; Johal, S.; Edmonds, M.S. Effects of dietary humic and butyric acid on growth performance and response to lipopolysaccharide in young pigs. J. Anim. Sci. 2014, 92, 4172-4179. [CrossRef]

48. Sanmiguel, R.P.; Rondón, I.B. Supplementation with humic substances affects the innate immunity in layer hens in posfasting phase. Rev. MVZ Córdoba 2016, 21, 5198-5210. [CrossRef]

49. Chen, C.H.; Liu, J.J.; Lu, F.J.; Yang, M.L.; Lee, Y.; Huang, T.S. The effect of humic acid on the adhesibility of neutrophils. Thromb. Res. 2002, 108, 67-76. [CrossRef]

50. Riede, U.N.; Zeck-Kapp, G.; Freudenberg, N.; Keller, H.U.; Seubert, B. Humate-induced activation of human granulocytes. Virchows Arch. B Cell Pathol. Incl. Mol. Pathol. 1991, 60, 27-34. [CrossRef] [PubMed] 
51. Luthala, M. Chicken CD4, CD8 $\alpha \beta$, and CD8 $\alpha \alpha$ T cell co-receptor molecules. Poult. Sci. 1998, 77, 1858-1873. [CrossRef] [PubMed]

52. Lee, I.K.; Gu, M.J.; Ko, K.H.; Bae, S.; Kim, G.; Jin, G.D.; Kim, E.B.; Kong, Y.Y.; Park, T.S.; Jung, H.J.; et al. Regulation of $\mathrm{CD}^{+} \mathrm{CD} 8^{-} \mathrm{CD} 25^{+}$and $\mathrm{CD} 4{ }^{+} \mathrm{CD} 8^{+} \mathrm{CD} 25^{+} \mathrm{T}$ cells by gut microbiota in chicken. Sci. Rep. 2018, 8, 8627. [CrossRef]

53. Salah, H.; Masour, E.S.; Reham, R.R.; El Hamid, E.S.A. Study on the effect of humic acid on growth performance, immunological, some blood parameters and control intestinal closterdium in broiler chickens. Zag. Vet. J. 2015, 43, 102-109. [CrossRef]

54. Vetvicka, V.; Baigorri, R.; Zamarreño, A.M.; Garcia-Mina, J.M.; Yvin, J.C. Glucan and Humic Acid: Synergistic Effects on the Immune System. J. Med. Food. 2010, 13, 863-869. [CrossRef]

55. Semantic Scholar Home Page. Effects of Humic Acid on Animals and Humans. An Overview of Literature and a Review of Current Research. Available online: https://www.semanticscholar.org/paper/Effects-of-Humic-Acid-on-Animals-andHumans-An-of-a/cc09ed93ae53f20b014315d0a53da6de278c36de (accessed on 7 June 2021).

56. Shermer, C.L.; Maciorowski, K.G.; Bailey, C.A.; Byers, F.M.; Ricke, S.C. Caecal metabolites and microbial populations in chickens consuming diets containing a mined humate compound. J. Sci. Food Agric. 1998, 77, 479-486. [CrossRef]

57. Buzoleva, L.S.; Sidorenko, M.L. Vliianie organicheskikh veshchestv guminovykh kislot na razmnozhenie énterobakteriu [Effect of organic composition of humic acids on Enterobacteria multiplication]. Zh. Mikrobiol. Epidemiol. Immunobiol. 2001, 2, 89-91. 